\title{
Military Duties and an Assassination Plot: The Extra Dimension Found in Ancient Egyptian Letters
}

\author{
SUSAN THORPE
}

\begin{abstract}
While current and previous research has provided considerable information regarding ancient Egyptian military campaigns, equipment, rank, and custom, this has come primarily from reliefs, inscriptions and military scribal documents. The personal touch found in private correspondence gives an extra dimension to these visual representations and official documents. This added aspect is evidenced in the following selection of letters from the Ramesside and Late Ramesside periods. Those from the Ramesside timeframe provide first-hand information about the responsibilities of a soldier's life in society when not involved in active service. They give insight into these duties and into the actual people involved, together with their personalities and issues. Still in a military context are four pieces of correspondence from a high-ranking general, dated to the Late Ramesside period. The first is concerned with care for the wounded. The other three are regarding an assassination plot involving the killing of two policemen and the means by which his recipients are to carry this out. This study, by its analysis and discussion of these pieces of personal correspondence, will illustrate the extra dimension such letters can provide-their importance as primary sources of societal and historical information that would otherwise remain unknown.
\end{abstract}

Prompted by a person's need to communicate in writing to a recipient at a distance, over the years private letters have been an important source of social and historical information. The personal correspondence from ancient Egypt exemplifies the extra insight that such letters can provide. They are a source of knowledge of the ancient Egyptian people, their personalities, their daily life, the issues that concerned them, their customs and beliefs. They are able to augment the information sourced from the images, reliefs and inscriptions found on temple walls, in tombs, tomb chapels and on personal stelae, giving an extra dimension to the scenes and texts portrayed there. To evidence this extra dimension the following study will look at a selection of letters from the Ramesside and Late Ramesside periods concerned with military related matters and issues. ${ }^{1}$

Current and previous research provides considerable information regarding ancient Egyptian military campaigns, equipment, rank and custom. This data has come from the study of monumental reliefs, inscriptions and military scribal documents. However, the visual images of battle scenes, such as those at Karnak of Seti I against the Libyans, ${ }^{2}$ at Luxor of Ramesses II fighting at the Battle of Kadesh, ${ }^{3}$ at Medinet Habu of Ramesses III against the Sea Peoples, ${ }^{4}$ appear as propagandistic representations of triumph over enemies. While they depict his men in battle around him, their focus is on the king's bravery and fighting skills.

From a textual perspective the inscriptions that accompany these images are also as focused on the majesty and bravery of the king and the defeat of his enemies rather than on his troops or individual soldiers. The "Bulletin" describes the king at the Battle of Kadesh as being:

\footnotetext{
${ }^{1}$ They have been selected from the "Military and Police Matters" section in my thesis "Social Aspects in Ancient Egyptian Personal Correspondence" (PhD diss., University of Auckland, 2016), as being relevant and representative of the topic being discussed in this article.

${ }^{2}$ Epigraphic Survey, The Battle Reliefs of King Seti I, RIK 4, OIP 107 (Chicago, 1986), pls. 28, 29.

${ }^{3}$ Wresz, Atlas 2, pl. 84.

${ }^{4}$ Epigraphic Survey, Earlier Historical Records of Ramses III, Medinet Habu 1, OIP 8 (Chicago, 1930), pls. 32, 36.
}

Journal of the American Research Center in Egypt 54 (2018), 175-185

doi: http://dx.doi.org/10.5913/jarce.54.2018.a014 
... like Sutekh great in strength, like Sekhmet in the moment of her fury.

His Majesty slew all the hostile ranks of the despicable Fallen One of Hatti....

and Ramesses states how:

I was after them like a griffon, I defeated all the foreign lands, being alone, My troops and chariotry abandoned me, none of them stood looking back.

Similarly, in the "Poem" he is:

Like fire in the instant that it devours....

Even a thousand men cannot withstand him, Hundreds-thousands despair just at the sight of him. ${ }^{6}$

Ramesses III in his battle against the Sea Peoples:

... is gone forth like a whirlwind against them....

His majesty is like an enraged lion, attacking his assailant with his paws; plundering on his right hand and powerful on his left hand, like Set destroying the serpent "Evil of Character."

In contrast to these visual and textual representations of military achievements on the battlefield is the personal information concerning everyday military life away from the battlefield that can be found in letters, such as the ones chosen for this study, dated to the timeframe of the above examples.

There has been considerable interest in the genre of ancient Egyptian letters. With regard to the Ramesside period, Allam has translated and discussed the letters from Maiseti. ${ }^{8}$ While each letter is accompanied by detailed notes covering language and discussion of content, there is not a focus on the personal information revealed about the sender in the context of a soldier's life in society rather than on the battlefield. In relation to the Late Ramesside correspondence, Černý comments that his notes "aim at concision and avoid any discussion concerning the content of the letters and the meaning of particular passages," as this aspect is "reserved for a special volume of translations and commentary." Such a volume has been provided by Wente. ${ }^{10}$ His translations are accompanied by extensive notes of grammatical comment and referencing, but when discussing his work he states that "my primary interest in translating these letters has been philological rather than historical...."11

This study will focus on the content of the letters to show how they provide first-hand information about the responsibilities, thoughts, and attitudes occurring in a soldier's life in society when away from the battlefield, give insight into the means by which the wounded were cared for and reveal details of a high-ranking general's assassination plot. "Personal" correspondence in the context of this study denotes a private letter between two people with regard to these aspects and the related issues that concern them. ${ }^{12}$ It will look at the knowledge gained about these senders and recipients, their occupations, personalities, and relationships, as well as the background of

\footnotetext{
${ }^{5}$ KRITA 2 (Oxford, 1996), 17, lines 96-97, 18, lines 106-107; M. Lichtheim, Ancient Egyptian Literature, vol. 2 (Berkeley, 1976), 60-71.

${ }^{6}$ KRITA 2: 3, lines 14-16; Lichtheim, AEL 2, 60-71.

7 W. Edgerton and J. Wilson, Historical Records of Ramses III: The Texts in Medinet Habu Volumes I and II, SAOG 12 (Chicago, 1936), 41-42.

${ }^{8}$ S. Allam, "Trois missives d'un commandant (Pap. CGC 58053-5)," ASAE 71 (1987), 4-12.

${ }^{9}$ Černý, $L R L$, VI.

${ }_{10}$ E. Wente, Late Ramesside Letters, SAOC 33 (Chicago, 1967).

11 Wente, $L R L, 1$.

12 That is personal in the sense that they are private letters between individuals, not addressed to royalty or the vizier and connected to court affairs or bureaucratic issues.
} 
other people involved in the correspondence. In this context a letter amongst those dealing with the assassination plot looks at the relationship between the sender Piankh and his recipient Nodjme with regard to their seeming emotional involvement or marital relationship. Also considered is the societal structure indicated by the forms of address in the selected letters.

Based on my translations of the primary sources and referencing of secondary sources, the study of each letter, will initially give an overview of content rather than a full translation of the complete text. Specific transliteration and translation of words and phrases will be included in the analysis in confirmation and discussion of the content. Where appropriate they will highlight possible differences in interpreting the transcription/translation that may, for example, affect the letter's message, the information regarding writer and recipient or the meaning of specific words in the context of the letter's topic. The individual analyses will also include primary source transliteration/translation to identify modes of address, grammatical points, historical context, and any emotional implication. ${ }^{13}$

\section{Military Duties and Responsibilities}

The following three letters from a standard-bearer named Maiseti, dated to the Nineteenth Dynasty, reign of Seti I, were discovered at Saqqara. The first letter, ${ }^{14}$ to the garrison commanders in the Northern region, is protesting their interference with the god's personnel on the Island of Amun, who are under the authority of the Royal Scribe Iuny. Maiseti states that if he learns that they continue to do this, they will be in trouble, as he is being reprimanded by pharaoh's officials. He asks them to pay attention to previous orders regarding the procurement of men, telling them to stop creating a disturbance in such an important place. He concludes with the order not to allow service to the god there to remain inactive-failure to do this will mean they will be jailed.

The name Maiseti is not one attested, but the form which begins with $m 3 j$, "lion" followed by the name of a divinity is not uncommon. ${ }^{15}$ The title of standard bearer implies that he was the person who actually carried the standard, but supportive evidence for this is lacking. The title could possibly "reflect a duty which he once performed personally, but which eventually came to be performed by his subordinates." ${ }^{.6}$ In this letter the people Maiseti addresses are described as $h r j j w^{c} y t$, "garrison captains." He addresses them in an extremely forceful manner to ensure they carry out his orders, writing $j h$ pw p3y.tn jri mjtt, "why do you act thus," ${ }^{17}$ and $j w . j r ~ \Upsilon h 3{ }^{3} 3$ $h n^{\complement} . t n$, "I shall reprimand you greatly," ${ }^{18}$ which supports his status of being a man in command. The designation makes it unclear whether the garrisons his recipients commanded were large or small. ${ }^{19}$ The style of greeting is

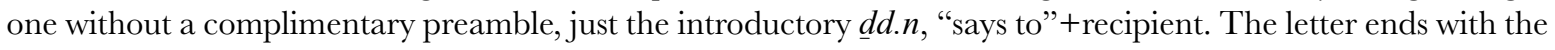
terse jh rh.k sw, "take notice of this," which Bakir notes as often present as a "curt injunction to inferiors" another indication of Maiseti's military rank and position.

The god's personnel of the Island of Amun, designated in the Edfu nome list as the capital of the Seventeenth Nome of Lower Egypt, were under the authority of the royal scribe Iuny, Lector and Administrator under Seti I. His titles are on several monuments and artefacts, i.e., kneeling statues of himself, a naos, a stela, a shabti-figure, and an amulet. On a double statue with his wife, he is named Chief of Secrets in the House of Morning, Royal Scribe, Chief Lector, Chief of the Priests of Sekhmet, Steward and Chief over Departments, Secretary of the Good God. He also has the title Dignitary and Administrator, one "whom the king has made great in the entire

\footnotetext{
${ }^{13}$ However, it should be noted that the focus of this study is not primarily a philological one.

${ }^{14}$ Primary and secondary source references for Pap. CGC 58053: KRI 1 (Oxford, 1969-), 322; Bakir, Epistolography, pls. I/ 1-II; Allam, "Trois missives," 4-12; E. Wente, Letters from Ancient Egypt, WAW 1 (Atlanta, 1990), 114, no. 133.

${ }^{15}$ Ranke, $P \mathcal{N} 1,144$.

${ }^{16}$ Schulman, Military Rank, 71.

${ }^{17}$ Cairo 58053, line 3.

18 Cairo 58053, line 5.

${ }^{19}$ Schulman, Military Rank, 50-51.

${ }^{20}$ Bakir, Epistolography, 68. J. Černý and S. Groll (Late Egyptian Grammar (Rome, 1993), 405) suggest that this should not be given an imperative interpretation. See also the discussion by Pascal Vernus, Future at Issue (New Haven, 1990), regarding clauses introduced by $j h$. In this context, Bakir's viewpoint is appropriate.
} 
land." ${ }^{21}$ The letter does not state the nature of the interference. However, the high-ranking positions Iuny held would mean any intrusion into the activities of those under his authority would lead to Maiseti being personally reprimanded in this way, resulting in Maiseti's strongly worded response to the garrison commanders. They must $t m r d t s \underline{d r} b 3 k n p 3 n \underline{t r}$, "not cause inactivity in the service to the god" ${ }^{22}$ or they will be $\underline{d} d h$, "imprisoned."

The word written for "letter" is $m \underline{d} 3 t t^{23}$ an Old Kingdom usage that in the New Kingdom came to mean, according to Bakir, "a document in a general sense in its rolled up state." ${ }^{24}$ Here the determinative used is the tree branch, implying this piece of correspondence was written on wood. Bakir suggests a "wooden tablet ... covered with plaster," a medium usually used "for notes of provisional character." ${ }^{25}$ It appears Maiseti was going about his duties dictating to a scribe who was taking notes, and who later created the finished letter on the papyrus found at Saqqara.

In the second letter ${ }^{26}$ Maiseti berates a soldier named Hat for arresting some laborers. He points out that the orders he issued earlier clearly identified whom Hat was to apprehend and asks whether this is a deliberate error, telling the soldier to address what he has done and put matters right by releasing the falsely arrested men. There follow several $k y \underline{d} d$, "further matters." He orders that any soldiers in the villages in the vicinity be rounded up and that any left in the villages be kept busy until he reaches Memphis. He states that none of his orders must be ignored, followed by an instruction to find some good men. On a very different topic is his next order to tend a pig, which a person named Neby will give him, and ensure there is no interference with anyone belonging to Neby. Returning to military matters, he instructs Hat not to allow soldiers to delay in the northern districts and to secure those marked who might try to evade the round-up. He concludes by repeating his order to find extremely good men.

Following the style of the previous letter, there is no complimentary preamble, just the introductory formula $\underline{d} d . n$, "says to" +recipient, but without the terse terminal $j \underline{h}$ rh.k $s w$, "take notice of this." In his address line Maiseti refers to himself as the $k 3 m$ T3-Nhsy, "Bull in Nubia." ${ }^{27}$ The designation "Bull in Nubia" would refer to the regiment of soldiers to which he belonged and which was attested as being in the Memphite region. ${ }^{28}$ Maiseti in his first order to Hat used the words "until I reach Memphis," so this appears to be confirmation of Maiseti's military location.

The status of the recipient Hat is $w^{\ulcorner} w$, "soldier" without the usual qualifying description to associate him with a specific army unit or to suggest a general association, for example with the king. The role was that of a serving soldier with a rank of infantryman, low in the military hierarchy, not a commander. References indicate that Hat would have been conscripted into the military and his training would have been severe, his duties and lifestyle harsh. ${ }^{29}$ The manner in which Maiseti addresses Hat emphasizes this and confirms his subordinate position to Maiseti, who accuses him of deliberately arresting the wrong men in order to $d h d h, j$, "humiliate me." He emphasizes a previous order rdj.n.j $m$ dr.t.k $m$ šs, "I gave to you by hand in writing," ${ }^{30}$ in which he had told Hat whom to $m h$, "seize." He tells him to $m t r n n$ jr.n.k, "examine this which you have done"s1 and not to retain them any longer.

His first "further matter" is to $\underline{h} \underline{t} \underline{t} t w^{\ulcorner} w$ nty $m d m j(w)$, "round up soldiers who are in the villages," ${ }^{32}$ suggesting the soldiers in question might be on inactive duty, tending their homes until being called upon. This could

\footnotetext{
${ }^{21}$ KRITA 1, 286-92.

22 Cairo 58053, verso, line 1.

23 Cairo 58053, line 7.

${ }^{24}$ Bakir, Epistolography, 18.

${ }^{25}$ Bakir, Epistolography, 19, although other contexts, $m \underline{d} 3 t$ with this determinative is used in to mean a wooden "peg" or "stake," q.v. P. Piccione, "The Md3.t, 'Peg,' in Ancient Egyptian," Serapis: The American Fournal of Egyptology 7 (1981-1982): 7586 passim.

${ }^{26}$ Primary and secondary source references for Pap. GGC 58054: KRI 1, 323-24; Bakir, Epistolography, pls. 2-3/III-IV; Allam, "Trois missives," 13-20; Wente, Letters, 115, no. 134.

27 Cairo 58054, verso.

${ }^{28}$ R. Faulkner, "A Statue of a Serpent-Worshipper," JEA 20 (1934), 155.

${ }^{29}$ Schulman, Military Rank, 36-37.

${ }^{30}$ Cairo 58054, line 4.

31 Cairo 58054, line 7.

32 Cairo 58054, lines 9-10; Wente, Letters, 115, no. 134. Alternatively Allam, "Trois missives," 13, renders as "bring for an inspection,"
} 
be an earlier example of the words of Ramesses II in the Kadesh Poem, when he talks of allowing his soldiers to sit in their villages "without performing the duty of an infantryman." 33 Maiseti tells Hat that if he allows any soldiers to jsk, "linger" they should $\operatorname{grg} n 3 g 3 w 3(t)^{34} n n 3$ hry-jhw $n n 3 d m j(w)$, "make ready the horses of the stablemasters ${ }^{35}$ in the villages." ${ }^{36}$

His next "further matters" is to tell Hat to make sure the orders given so far are carried out and that he is to procure especially (emphasized) good men (rmt $n f r s p$-sn). Returning to the "round up" of soldiers, Maiseti refers to $\underline{d} b^{c}(w) n b$ nty jw.s $<n>r$ - wh, "all the sealed men who try to escape" ${ }^{\text {"37 }}$ and advises $m h$ tw jm $s n \underline{d} d \underline{d} r$, "seize hold of them very securely." ${ }^{\prime 8}$ The fact that they might try to escape indicates a nonvoluntary situation. The mention of a form of marking suggests a means of conscript identification, apparent confirmation of other references indicative of the conscription process. ${ }^{39}$ In his final words Maiseti once more exhorts Hat to put together a jst nfr sp-sn, "an especially good company." 40

This piece of correspondence gives insight into some matters which an ordinary $w^{\complement} w$, "soldier" could be asked to look into. From a military perspective, while they are not mentioned, and Hat has not been associated with a particular unit, there must have been other soldiers with him to assist in carrying out his orders. It is Hat whom Maiseti has tasked with the organization, but rounding up soldiers, procuring men, and seizing escapees would need additional followers. So in his role as "soldier" Hat appears to have additional responsibility, reflecting a hierarchy, perhaps an unofficial one, amongst infantrymen when circumstances demanded it. In contrast is the matter, unrelated to a military issue, which is Maiseti's order to Hat to jni tw.k $\breve{s} 3$, "fetch the pig," which will be given to him by Neby, to $s 3 w . s$, "take care of it" and make sure Neby's family are not mistreated. Appearing in the middle of the letter as an abrupt change of topic amongst Maiseti's other orders-a thought that has apparently suddenly occurred to him—this request adds a personal touch to the military issues that have been concerning him.

The third piece of correspondence ${ }^{41}$ from Maiseti is to yet another person named Hat. Apparently, he had previously told this Hat to mobilize sometime soon, but now warns him in this letter against doing anything until he has received a message. The mobilization in question is apparently related to a prison in Hat's charge. The message will be that someone is coming to fetch the prisoners, in which case he will be told to come with them. Maiseti tells him to make sure everyone is accounted for, and if he fails, Maiseti threatens to kill him. He follows this threat with a polite request for a good piece of rope to replace one which has been stolen.

This letter omits the formula $\underline{d} d n$, "says to" in the opening address. Instead it uses just the brief $n$, "to" recipient style, concluding as in the first letter with the form $j h$ rh. $k s w$, "take notice of this." The address line refers to Hat as being "of the Island of Debu," together with his role as "3-n-št "Chief Taxing Master," a title that also appears in the greeting. Maiseti refers to a previous letter in which he told Hat to thm $d w$ 3, "move tomorrow," but now he tells him to $p t r n . k b^{\ulcorner} s p$-sn, "look to yourself very carefully," and not to thm $p 3 y . k j t h$ `?, "move your prison there." He is to wait, since if wn.tw hr jjt r jnt $n 3$ n jthw nty $m p$ 3 jw, "one comes to fetch the men of the prison on the island," he will get a message jmi jj $h n^{`}$ sn, "come together with them." Maiseti orders Hat to make sure everyone in his charge is accounted for, telling him $m r d t$ snj.tw $w^{\ulcorner} n t y ~ m \underline{d r t .}$, "do not cause one to call in

\footnotetext{
and at $16(\mathrm{p})$ notes background and references regarding usage of $\underline{h} t \underline{h t}$ in other contexts and the reasoning for his interpretation. Either translation seems appropriate here.

${ }^{33}$ Schulman, Military Rank, 114, ref. 159.

${ }^{34}$ For background and references to the rendering of $g 3 w 3(t)$ as "horses," see Allam, "Trois missives," $17(\mathrm{u})$.

35 See Schulman, Military Rank, 51-53 regarding the duties of a stablemaster, and references that would indicate he would not have had an active military role.

${ }^{36}$ Cairo 58054, line 12.

37 Cairo 58054, verso, line 6.

${ }^{38}$ Cairo 58054, verso, line 7.

39 Schulman, Military Rank, 76.

40 The word $j$ st was primarily used to relate to the crew of a ship, but here has been used to denote a land-based company. For full background for usage see Černý, Community, 99-100.

${ }^{41}$ Primary and secondary source references for Pap. CGG 58055: KRI I (1969-), 323-24; Bakir, Epistolography, pls.2-3/III-IV; Wente, Letters, 115, no. 134 .
} 
question a single one in your hand." ${ }^{42} \mathrm{He}$ adds even further emphasis to his orders by writing $s 3 w . t w w h 3 n k h r w$ $n$ ' $n h$ $r$ ' - $p w j w . k r m t h r d r t . j$, "guard yourself, seek you one day of life, or else you will die under my hand." ${ }^{3}$

Similar to the abrupt change of subject in the previous letter, the next matter is an order for $k y n w h n f r s p$ $s n$, "another really good rope," $p$ 3 wn jtj.tw $p 3$ nty $h n$ '.n, "because the one which was with us has been taken." While Allam notes that $n w h$, "rope" used here, has in many cases been associated with boats, ${ }^{45}$ it is unclear in this context to what use it is being put. The request is in sharp contrast to Maiseti's death threat. It suggests a calming breath after the forcefulness of his previous words before attending to a more practical matter-as in the previous letter, reflecting a more personal aspect to Maiseti, the military commander.

The information in this piece of correspondence shows that an administrative civilian, such as the $3-n-\check{s} t$, "Chief Taxing Master" ${ }^{46}$ was also responsible for a prison and the moving of its inmates. He was expected to respond to orders from a military commander such as Maiseti, with the threat of possible death if he was slack in fulfilling the responsibility. The location of Debu is not given, but the reference establishes knowledge of the existence of what was possibly a military prison. However, while it is a military commander who is issuing the orders regarding prisoner movement, the responsibility could be an administrative one with no military connection. The content has been another source of insight into the issues concerning a soldier when away from the battlefield.

These three letters from Maiseti have detailed the varied duties which could come under the remit of one with the title "standard-bearer," covering as they do a complaint about interference with religious personnel, issues with a subordinate regarding wrongful arrest, the conscription and rounding up of soldiers and the movement of prisoners. The forms of address in the letters reflect Maiseti's status. The first two are in the $\underline{d} d . n$, "says to" recipient style, while the third letter is just the brief $n$, "to" recipient. All three have no complimentary preamble in keeping with direct orders from a military commander to his subordinates. While Maiseti's authoritative personality is revealed by the tone of his commands and the threats he makes, a more "personal" aspect is shown by his sudden concern about a pig and the need for some good rope. References in the letters to other people and locations prompted research into the background of an official such as Iuny, noted the authority given to the soldier Hat, identified the existence of the Island of Debu and its prison-possibly a military one.

\section{A Charioteer's Concerns}

A further piece of Nineteenth Dynasty correspondence, dated to the reign of Ramesses II, is from a scribe, Kenyamon to a charioteer Huy. ${ }^{47} \mathrm{He}$ is replying to a previous letter from Huy to advise him he has complied with the requests that Huy had made - to attend to the people under Huy's supervision, to see to the welfare of his horses, and to give grain rations to the soldiers and the Apiru who are drawing water from the well of PreRamessess, south of Memphis. He notes that Huy will not find fault with him, as he is giving grain to the horses daily and has taken note of his instruction regarding the food for the soldiers and the Apiru.

Kenyamon's title is given as "scribe" with no other affiliation. He precedes his address to Huy with a complimentary preamble in honor of Ramesses II, in which he associates the king with Horus, Mighty Bull, beloved of Ma'at, the Two Ladies, Re, Horus of Gold, and as being "the son of Re, Ramesses II 1.p.h., given life forever and ever like Re." This preamble is appropriate for a letter to the charioteer Huy whom Kenyamon notes is "of the stable of Ramesses II." So, he has employed the simple sender-to-recipient address formula $h r s w \underline{d} 3-j b n$ $n b . f$, which by now come to mean a "communication." ${ }^{38}$ He concludes by saying $n f r$ snb. $k$, "May your health

\footnotetext{
42 Cairo 58055, lines 3-6.

43 Cairo 58055, line 6-7. Allam, 23, n. (v) notes a similar expression occurring; KRI II, 53,15.

44 Cairo 58055, line 8.

45 Allam, "Trois missives," 24, n. (y). See also Janssen, Prices, 438-39.

46 For comment and background on '3-n-št, see S. Katary, Land Tenure in the Ramesside Period (London, 1989$), 197$.

47 Primary and secondary source references for Pap. Leiden 1,349 vs.: KRI III (1969-), 250-51; Bakir, Epistolography, pls. 17-18/XXIIIXXIV; Wente, Letters, 123, no. 145.

48 Bakir, Epistolography, 43.
} 
be good," which at this time was used by the sender to a person of superior or equal rank. In this case probably the former.

The people to whom Kenyamon has been asked to attend are referred to by Huy as $r m \underline{t} n t r-h{ }^{\imath} t . j$, "the people under my supervision," so it is unclear that they are military personnel. The horses are referred to as htr, a pair or yoke of animals consistent with Huy's profession as $k \underline{d n} n$, "charioteer." Kenyamon describes them as being $n f r$ $s p-s n$, "extremely good!" As a charioteer, Huy would have been one of two. While $k \underline{d n}$ was used for the actual driver of the chariot, in some instances he is shown engaged in fighting from the chariot and bearing a shield to protect the other occupant. ${ }^{49}$ Hoffmeier notes the first appearance of this second person, termed snny, "chariot warrior," in the time of Tutankhamun. ${ }^{50}$

The soldiers, who together with the Apiru are drawing water from the well, are $r m \underline{t}-m \check{s}^{c}$, which is a term attested only in the Nineteenth Dynasty to distinguish soldiers from men of the chariotry. Earlier in the time of Tuthmosis III, Apiru are represented as wine-makers in the Theban tombs of the herald Intef (TT 155) and the Second Prophet of Amun Puyemre (TT 139). Then as a separate people, they were noted as captives on the Memphis stela of Amenophis II..$^{51}$ Their continuing role as workers during the time of Ramesses II is attested in Leiden P.348 where they are noted as jth jnr $r$ t3 bhnt 3 $n$.... $R^{\complement}-m s-s w$ mry-Jmn, "dragging stone to the great pylon of ... Ramses-maiamun." 52 They are also mentioned on an ostracon, possibly from the Theban area. This somewhat fragmented text refers to $\underline{d} b . t$. "bricks" (rather than stones) being quarried by the Apiru under the direction of $n 3$ rmt-m $\check{s}^{\ulcorner} n$ imnt, "the army men of the Right (side)," noting the total number as twenty. ${ }^{53}$ In the context of the current letter, they are also described as jth. "dragging," but in this case it is from a hnmt, "well" and so can be rendered as "drawing," presumably water, although this is not stated specifically. Whether they are willing or captive workers is unclear, as other than the Memphis stela inscription (which could be a boastful claim), there appears to be no specific reference to the Apiru as an enemy. ${ }^{54}$

From a social aspect, the content of the letter has shown that a person of scribal status was expected to accept orders from one of the military, such as the charioteer Huy, and undertake tasks of administration and provisioning at his bequest. The matters to which Kenyamon refers indicate the concern that a charioteer had for the well-being of his horses, as well as for people in his charge. Kenyamon's status in the social structure is emphasized by the inclusion of a preamble in honor of the king, showing the deference of the writer to royalty before addressing a straightforward "communication" to his charioteer recipient, acknowledging Huy's status by noting he is "of the stable of Ramesses II." Huy's locations is not stated, nor whether he was involved in any military related activity. It is possible he had returned home to remain in reserve temporarily, as Wente has noted, "the personnel of the chariotry were not always obliged to be on active service." ${ }^{55}$ This piece of correspondence confirms the separate designation of the infantry from the chariotry, showing that ordinary soldiers could be employed to do manual work in conjunction with foreign labor.

\footnotetext{
${ }^{49}$ Schulman, Military Rank, 67.

50 J. Hoffmeier, "Observations on the Evolving Chariot Wheel in the 18th Dynasty," FARCE 13 (1976), 44; see also A. Spalinger, War in Ancient Egypt (Oxford, 2005), 176-77.

51 Peter Der Manuelian, Studies in the Reign of Amenophis II (Hildesheim, 1987), 226.

52 Gardiner, LEM, 134-35, verso, 6-7.

53 See K. Kitchen, "High, Middle and Low Ramesside Life, from Thebes to Pi-Ramesse," in E. Černý et al., eds., Timelines Studies in Honour of Manfred Bietak, vol. 1 (Leuven, 2006), 183-84; Yvan Koenig, Les ostraca hiératiques inédits de la Bibliothèque Nationale et Universitaire de Strasbourg (Cairo, 1997), pl. 96.

${ }^{54}$ For a discussion regarding texts which concern the Apiru in various situations and contexts see James Hoch, Semitic Words in Egyptian Texts of the New Kingdom and Third Intermediate Period (Princeton, 1994), \#70.

${ }_{55}$ Schulman, Military Rank, 16.
} 


\section{Care for the Wounded}

Further insight into military issues in a social context occurs in the following personal correspondence from the Late Ramesside period, dated to Year 10 of the Renaissance. ${ }^{56}$ The sender of the letters, identified as Piankh, ${ }^{57}$ gives himself the title wr mš $n$ pr-?, "the general of Pharaoh."

The first letter is to the scribe Tjaroy telling him to send some cloth rags to be made into strips for bandages for the men. ${ }^{58}$ The general notes that his recipient knows about the journey he is going to make and his final words emphasize the urgency of his request.

While Piankh addresses his recipient as ţrry, "Tjaroy," this person was in fact Dhutmose, the Scribe of the Necropolis in the time of Ramesses XI. The two names occur together in many letters..$^{59}$ The most comprehensive overview to show that this was one and the same person has come from Černý, although he comments, "why the surname Tjaroy was given to Dhutmose escapes us completely." ${ }^{\prime 60}$ The address in this brief letter is with the short formula- $n$, "to" with no elaborate greeting, a style appropriate for an order from a high ranking general.

Despite its brevity, this request provides information regarding military movement and medical requirements. The letter indicates a location for Piankh away from ongoing military involvement, as he states he is about to make a $n^{\prime} y$, "journey," implying that he was about to embark on a campaign, a venture in which he expected casualties, which is the reason for bandages. Given the dating of the letter, together with the reason for writing, this could have been the military move into Nubia against Panhesi ${ }^{61}$ from a location south of Thebes. ${ }^{62}$ An imminent departure is indicated by the urgency in the letter, when the general urges Tjaroy to act wnn spr.k, "as

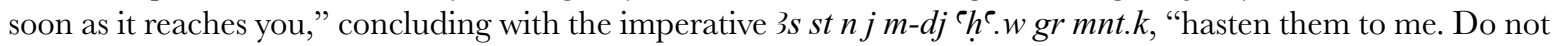
delay any more on your part." ${ }^{\prime 3}$ This piece of correspondence is a source of information regarding care of the injured, providing evidence of the resources to tend the wounded-the use and need of hbs jsw m r $r k k n w$, "many bound clothes rags," ${ }^{\prime 4}$ which would be made into pry $r$ wt rmt , "strips to bandage the men." ${ }^{65}$

\section{An Assassination Plot}

In contrast to the practical nature of the previous letter are the next three pieces of correspondence from Piankh, all regarding the same issue-the assassination of two policemen and the way in which he wants their killing to be carried out. They were acquired by the Berlin Museum from an antiquities dealer in Luxor. The three separate letters, addressed to three different people, were wrapped together in a single roll. ${ }^{66}$

The first letter, addressed to Tjaroy, is in reply to a previous letter Piankh has received from him. ${ }^{67}$ The general writes that he has noted all the issues in the letter, and then he refers to the remark Tjaroy made of the matter of the two $m \underline{d} 3 y w$, "policemen" $\left.{ }^{68} r-\underline{d} d \underline{d} d \boldsymbol{d} n 3 y\right) m d w t$ "saying, "They spoke these charges." ${ }^{69}$ He tells Tjaroy to join up with Nodjme and Payshuuben. He instructs him $m t w$ dj ini.tw p3y md $33 y w 2$ r p3y pr, "you have the two

\footnotetext{
56 Wente, "Chronology of the Letters," in $L R L, 16$.

57 Kenneth Kitchen, The Third Intermediate Period in Egypt (Warminster, 1986), 41, n. 170; Wente, LRL, 8.

58 Primary and secondary source references for Pap. Bibliotheque Nationale 197, V: Ćerný, LRL, 34-36; Wente, LRL, 52-53; Wente Letters, 182, no. 300 .

59 For example Wente, $L R L$ 1, 18; LRL 14, 46.

60 Černý, Community, 363-66.

61 So Wente, LRL, 8, 12.

62 Wente, LRL, 16.

63 Verso, line 4.

64 Lines 3-4.

65 Verso, line 2.

66 Alan Gardiner, "A Political Crime in Ancient Egypt," fMEOS 2 (1912-1913), 57.

67 Primary and secondary source references for Pap. Berlin 10487: Černý, LRL, 36; Wente, LRL, 53; Wente, Letters, 183 , no. 301.

68 Over time, a nationwide police force grew out of semimilitary units securing the borders, consisting in large part of Nubian Md $3 y$ w policing the frontier region of the country. In the New Kingdom the ethnonym for these mercenaries had become synonymous with "police" and their presence noted in such locations as the Valley of the Kings/Deir el-Medina.

69 Line 3.
} 
policemen brought to this house" and $m t w$ jn-phwy nзy $m d w t$ m-sšr sp-sn, "get to the bottom of their charges in short order." ${ }^{\prime 0}$ What the two policemen have said is not revealed, but the general orders that if Payshuuben and Nodjme decide the charges are true, then jw nty $r d j s w<m>m s t j 2 m t w-w h \jmath^{\top}<w ~ m>p$ ? $m w$ w grh, "put them [in] two baskets and you throw them [into] the water in the night." But $m d j{ }^{\top} m r m t n b n p$ ? $t$, "not allow anyone to know in the land."

The second letter is in reply to Payshuuben ${ }^{72}$ who had evidently also written to the general about charges made by the two policemen. He is told to join up with Nodjme and Tjaroy, and he is also instructed to bring the two policemen to the house and ascertain their charges in short order. Piankh does not repeat his comment that he expects Payshuuben and Nodjme to determine whether the charges are true. He appears to expect Tjaroy to pass on this request. If they prove correct Payshuuben is ordered to $\underline{h} d b$, "kill [them]" before throwing them into the water by night. While Piankh also tells him not to let anybody in the land find out, he does not mention putting them into baskets.

The third letter is in reply to Nodjme,$^{73}$ who has written to him about the two policemen. Piankh tells her to join up with Payshuuben and Tjaroy and gives her the same instructions-to bring the policemen brought to the house and quickly learn of their charges. As in the letter to Payshuuben, he does not tell her to determine if the charges are true, nor tor put them in baskets. He also omits the injunction not to let anybody in this land find

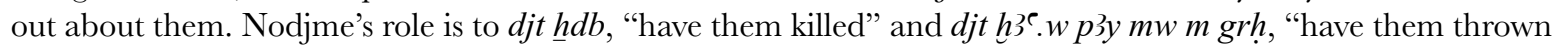
[into] the water by night."

The charges made by the policemen that have so angered Piankh are not specified. The fact they must be killed if the charges are true implies that whatever they have disclosed must be kept secret, or they are to be punished for what they have done. In summary, Tjaroy is ordered to put the men into mstj 2, "two baskets," Payshuuben is expressly ordered to $\underline{h} d b$, "kill" them, while Nodjme is told $m t w . t d j t \underline{h} d b .<w>$, "you have them killed." Each of them is told $m t w . k h 3$. $w<m>p 3 m w m$ grh. "you throw them into the water by night," but Nodjme is told $m t w . t$ djt $h 3$ ?. $w p 3 m$, "you have them thrown into the water." by the fact that this has to be done at night, and as regards Tjaroy and Payshuuben, they must $m \mathrm{dj}^{\mathrm{C}} \mathrm{r} r \mathrm{rm} t \mathrm{nb} n$ $p 3 t$, "not allow anyone to know in the land." ${ }^{75}$ So the sequence of events when Tjaroy, Payshuuben and Nodjme got together and exchanged instructions would have been that Nodjme oversaw events and was responsible for seeing Piaknh's orders carried out, Payshuuben was to be the person to carry out the killing, and Tjaroy was then to put the bodies into two baskets before they were thrown into the water..

The letters to Tjaroy and that to Nodjme have an external address which is lacking in the letter to Payshuuben. The rendering of these external addresses is different. The address line for Tjaroy's has been translated "from" Payshuuben "to" Kenykhnum" and for Nodjme's "from" Nodjme "to" Kenykhnum. ${ }^{76}$ The interpretation being that after reading them the respective recipients returned the letter to the general's scribe, and that the reason for the lack of an external address on Payshuuben's letter was that he had sent it back together with Tjaroy's. In his later translations Wente has rendered "to" Payshuuben "from" Kenykhnum and "to" Nodjme "from" Kenykhnum. ${ }^{77}$

This presumes that Tjaroy's letter initially went together with Payshuuben's, who then passed it on to Tjaroy.

The former interpretations could mean that Piankh's instructions needed to be acknowledged by returning the letters, evidencing that they had been received and read. This could account for the fact that they were all found together in a roll. The latter amended translations appear more logical, but the former seems more in keeping with the secrecy ordered by Piankh. ${ }^{78}$

\footnotetext{
70 Lines $4-6$.

71 Lines 7-8.

72 Primary and secondary source references for Pap. Berlin 10488: Černý, LRL, 53-54; Wente, LRL, 69; Wente, Letters, 183 , no. 302.

73 Primary and secondary source references for Pap. Berlin 10489: Černý, LRL, 54; Wente, LRL, 69; Wente, Letters, 183 , no. 303.

74 Černý, $L R L, 54$, no. 35, verso, line 2. The additional emphasis added by the use of this form of $r d j$ "cause."

75 Černý, LRL, 36, no. 21, line 8; 54, no. 34, verso, 1.

76 See Gardiner "Political Crime," 63; Wente, $L R L, 53$, no. 21, 69, no. 35; Černý, LRL, xxi, xxiv.

77 Wente, LRL, 183, Letters, 301, 303.

78 Alternatively the fact they were found wrapped together in a roll could mean they were never sent.
} 
The introductory address in the letters is in the brief $n$, "to" recipient style, commensurate with Piankh's authority and the issuing of an order. Payshuuben is referred to as the general's $r w \underline{d}$, "agent" or inspector but no further background is given. The third letter to Nodjme designates her as "the great one of the harem of AmunRe," the špst, "noble lady," Nodjme. There follows an elaborate greeting in which Piankh asks that she be kept alive and healthy by $n \underline{t r} n b$ ntr.t $n b r$-nty $t w . j(h r) s n . j$, "every god and every goddess whom I pass,"79 so that when he returns he can $m t w<. j>m h$ jrt.tw $<. j m>p t r . t r^{\ulcorner} n b s p<s n>$, "fill my eyes with the sight of you every day." The inclusion of the intensifying particle appears to imply some emotional attachment between the two. ${ }^{81}$ The nature of their relationship has been the subject of much speculation. Kitchen associated with Herihor, Piankh and Pinudjem, and argued that she was in fact Herihor's wife, Piankh's mother, and grandmother to Pinudjem. ${ }^{82}$ The role of grandmother was prompted by the title "King's Mother" in various funerary inscriptions, an attestation which is cited as not being a possibility ${ }^{83}$ Based on additional evidence from the Temple of Khons at Karnak, Kitchen subsequently proposed that Nodjme was in fact the daughter of Herere, an earlier principal of the harem of Amun-Re, (Herere A), that she was the wife of Herihor and mother to a daughter also named Herere (Herere B) who was married to Piankh. She was therefore Piankh's mother-in-law. ${ }^{84}$ An alternative genealogy has been suggested by Taylor ${ }^{85}$ who, after reviewing in detail the arguments of Kitchen and others, put forward the hypothesis that Herere A was the mother of Piankh, that Nodjme was his wife, and Pinudjem their son. He also suggested that Nodjme was later the wife of Herihor.

Piankh's tone in this third letter would appear to reflect a husband/wife relationship. He addresses her in a manner totally contrastive to the abrupt authoritative manner of the first two letters, and which is present in his other correspondence. Personal feelings are evident in his desire (emphasized) to "fill his eyes with the sight of her," and the fact that he is asking her to ensure the killing of the two policemen by writing $m t w . t d j t \underline{h} d b .<w>$, "you have (them) killed," ${ }^{\prime 6}$ suggests the trust of a spousal relationship. ${ }^{87}$ Her involvement is an example of the power and authority that a high-ranking woman such as Nodjme—wrt hnrt, "Great one of the harem" and špst, "noble lady"—could exercise.

Returning to the first piece of correspondence to Tjaroy, after detailing his instructions regarding the two policemen, the general continues by asking how Pharaoh will reach this land, and whose superior is he after all? He then asks Tjaroy why, although he has sent a barge, three months have gone by and he has not sent him a deben of gold nor a deben of silver either, with the additional comment, "That is alright. Do not worry about what ... he has done." The general concludes by demanding that these amounts should be sent by barge as soon as Tjaroy gets the letter.

From a historical perspective Ramesses XI was still Pharaoh in name, ruling over a country that was now divided into two regions-northern and southern. In the southern region, with its center at Thebes and a northern boundary at el-Hibeh, his power had been gradually usurped. As commander of the army at this time Piankh's military efforts were directed against Panhesy in Nubia in order to implement the new administrative structure and bring Nubia back under Theban control. ${ }^{88}$ His words regarding the Pharaoh appear to confirm the current political situation in which the influence and administrative control of Ramesses XI had diminished. Piankh asks with additional emphasis $j r . f p h p 3 y t 3 m j-j h s p$-sn, "how will he reach this land," ${ }^{89}$ presumably Nubia, and he

\footnotetext{
79 Černý, $L R L, 54$, no. 35, lines 2-3.

80 Černý, LRL, 54, no. 35, line 4.

81 K. Ridealgh, "Yes Sir! An Analysis of the Superior/Subordinate Relationship in the Late Ramesside Letters," LingAeg 21 (2013), 186, notes that "no other letters sent by Piankh have survived that include this emotional overtone."

82 Kitchen, Third Intermediate Period, 40-43.

83 See E. Wente, "On the Chronology of the Twenty-First Dynasty," fEA 26 (1967), 174, n. 148.

84 Kitchen, The Third Intermediate Period, 536.

85 J. Taylor, "Nodjmet, Payankh and Herihor: The End of the New Kingdom Reconsidered," in Christopher Eyre, ed., Proceedings of the Seventh International Conference of Egyptologists (Leuven, 1998), 1142-55.

86 Černý, $L R L, 54$, no. 35, verso, Line 2.

87 See Taylor, "Nodjmet, Payankh and Herihor," 1150-51 for further supporting arguments for this relationship.

88 Kitchen, Third Intermediate Period, 248-53.

89 Černý, LRL, 36, no. 21, line 9.
} 
rather derisively asks, $h r-j r p r-\bigodot^{-} n(y) m$ hry $m-r$ - ${ }^{-}$, "Further as for Pharoah, who anyway is superior?" ${ }^{90}$ It is now himself who holds the reins of power. As Ridealgh noted, this "indicates not only a high level of trust between Piankh and his subordinate, but also reinforces the lack of Pharaonic power in the Theban area...."91

Following his command to Tjaroy to send him gold and silver by barge after a time lapse of three months, he tells his recipient with emphasis $s w$ m-š̌r $s p$ sn, "It is alright" $m$-dj ḩ3ty. $k$ p $3 y$ ir .f, "do not worry (about) what he has done," $" 92$ a reminder to Tjaroy that Piankh is now the correct recipient of such goods.

These three letters have confirmed the importance of such personal correspondence as a source of knowledge about events occurring in ancient Egyptian life. In this case evidence regarding a conspiracy to assassinate policemen, sanctioned by Piankh, the general of Pharaoh, and overseen by such a high-ranking personage as Nodjme. Her involvement and the manner in which Piankh greets her resulted in research that attested to a relationship as his wife, so there is the implication of marital influence and obedience. His manner of address reveals another side to Piankh's authoritative personality, expressing personal feelings and emotions that are rarely found in personal correspondence, especially by a high-ranking military commander. In addition from an historical perspective, the first letter to Tjaroy reflects the decline of the king's authority, and it indicates the status Piankh felt he had in relation to him.

\section{Conclusion}

With regard to military life, this study demonstrates an extra dimension into the lives of the people involved, their personalities and relationships, which is revealed through their personal correspondence, as opposed to the visual representations of battle scenes with their related inscriptions and texts.

The reasons for writing that had prompted these letters have given insight into military related requirements and issues in society. The Ramesside letters detailed the varied responsibilities that could be part of a soldier's life, providing an insight into the integration of military and administrative duties within the societal structure. Piankh's correspondence, initiated while away from the battlefield, firstly provides information about military care for the wounded. Secondly, on a very different topic, it reveals details of an assassination conspiracy, painting a dramatic picture of the way in which the killing of the two policemen was to be carried out-further evidence of a military context for the extra dimension.

The analysis of the correspondence has detailed the various forms of address used by the senders and shown the ways in which differing styles are related to the content of the letter and status in the social hierarchy. The senders and recipients of the letters have been identified, together with their occupations and status within the hierarchy. Research has discovered the background of other people mentioned in the letter and their relationship to the sender and/or the recipient as well as establishing historical context.

There has been no overt "self-presentation" by the writer. The initiators of these letters have not included any specific detail of personal background or achievements in the context of historical or social events, either as information additional to the reason for writing, or as a possible record for posterity. Their emphasis is on the practical matters of military duty and responsibilities and on the manner in which two policemen should be assassinated. There are only a few instances in which emotions or personal feelings are implied or expressed.

In conclusion, while evidence from visual representations and official textual documents are valuable sources regarding Egyptian military campaigns and achievements, this study demonstrates the importance of personal correspondences as additional primary sources in this context. Their distinctiveness lies in the insight they provide at a personal level—insight that has added an important extra dimension to our knowledge of a soldier's duties and responsibilities within Egyptian society and even of an assassination conspiracy, knowledge that would otherwise have remained unknown.

University of Auckland

\footnotetext{
90 Černý, $L R L, 36$, no. 21, verso, line 1.

${ }_{91}$ Ridealgh, "Yes Sir! An Analysis," 194.

92 Černý, $L R L, 36$, no. 21, verso, line 3.
} 
